Вісник Львівського торговельно-економічного університету. Юридичні науки. 2019. Вип. 8.

\title{
УДК 343.27
}

Резнік Я. А., помічник судді

господарського суду міста Києва

M. Kü̈в.

ORCID ID: 0000-0002-5355-7131

\section{ЗМОВА НА ВЧИНЕННЯ ПРОТИПРАВНИХ ДІЙ ЯК ПІДТАВА ЗАСТОСУВАННЯ ЗАХОДІВ КРИМІНАЛЬНО-ПРАВОВОГО ХАРАКТЕРУ ЩОДО ЮРИДИЧНИХ ОСІБ}

Анотація. Метою статті є встановлення доиільності застосування заходів кримінально-правового характеру щздо юридичних осіб за вчинення уповноваженою особою від імені та в інтересах юридичної особи змови на вчинення протиправних дій. На виконання поставлених завдань зроблено такі основні висновки. Змова є іманентною властивістю співучасті у злочині та притаманна всім формам співучасті, що перераховані у ст. $28 \mathrm{KK}$ Украӥни. У кожній з иих форм змова відрізняється якісною ознакою: чим більш небезпечною є форма співучасті у злочині, тим більш складною повинна бути змова між співучасниками. Змова притаманна як для співучасті «особливого» роду, так і для співучасті з розподілом ролей, коли для кримінально-правової кваліфікації дій осіб потрібно визначати роль кожного співучасника у вчиненому діянні. За змову уповноважених осіб, які вчиняють злочини від імені та (або) в інтересах юридичної особи, щуодо юридичних осіб застосовуються заходи кримінально-правового характеру, у випадку, якщо кваліфікуючою ознакою злочинів, названих у ст. 96-3 КK Украӥни, є вчинення їх за попередньою змовою групою осіб або організованою групою. Окрім того, застосування таких заходів можливе у випадку передбачення кримінальної відповідальності створення та діяльність організованих форм співучасті. Запропоновано розширити перелік злочинів у n. 4 ч. $1 \mathrm{~cm}$. 96-3 КК України шляхом вказівки на злочини, передбачені у ч. 5 cm. 143 (участь у транснаціональних організаціях, щзо здійснюють незаконну торгівлю анатомічними матеріалами людини), статтях 255 (створення злочинної організаиії, 257 (бандитизм). Виявлено прогалину у правовому регулюванні у частині відсутності у нормах розділу XIV-1 Загальної частини КК Украӥни вказівки на те, щуо уповноважена особа може вчинити злочин від імені та в інтересах юридичної особи самостійно або у співучасті. Запропоновано шляхи на ї̈ усунення.

Ключові слова: змова на вчинення протиправних дій; співучасть у злочині; заходи кримінально-правового характеру; юридична особа; уповноважена особа.

Reznik J. A., Assistant Judge

Economic Court of Kyiv,

Kyiv 
Вісник Львівського торговельно-економічного університету. Юридичні науки. 2019. Вип. 8.

\section{CONSPIRACY TO COMMIT UNLAWFUL ACTS AS A GROUND APPLICATION OF MEASURES OF CRIMINAL LAW FOR LEGAL PERSONS}

Abstract. The purpose of the article is to establish the appropriateness of the criminal-law measures against legal entities for the commission by an authorized person on the behalf and in the interests of a legal entity of a conspiracy to commit unlawful actions. To accomplish the tasks, the following main conclusions were made. Conspiracy is an inherent property of complicity in a crime and is inherent in all forms of complicity listed in Article 28 of the Criminal Code of Ukraine. In each of these forms the conspiracy is characterized by a qualitative sign: the more dangerous is the form of complicity in the crime, the more complex the conspiracy between the accomplices should be. The conspiracy is inherent both for the complicity of the "special" kind, and for participation with the distribution of roles, when for the criminal-legal qualification of actions of persons it is necessary to determine the role of each accomplice in the committed act. By conspiracy of authorized persons who commit crimes on behalf and (or) in the interests of a legal entity, legal persons are subject to criminal-law measures, if the qualifying element of the crimes referred to in Article 96-3 of the Criminal Code of Ukraine is the commission of them for by prior conspiracy by a group of people or an organized group. In addition, the use of such measures is possible in the event of criminal prosecution of the creation and operation of organized forms of complicity. It is proposed to expand the list of crimes in paragraph 4 of paragraph 1 of Article 96-3 of the Criminal Code of Ukraine by indicating the crimes envisaged in paragraph 5 of Article 143 (participation in transnational organizations engaged in the illicit trade in human anatomical materials), in articles 255 (creation of a criminal organization), 257 (banditry). The gap in the legal regulation was revealed in the part of absence in the norms of section XIV-1 of the General part of the Criminal Code of Ukraine indications that an authorized person may commit a crime on behalf of and in the interests of a legal entity independently or in complicity. Proposed ways to eliminate it.

Key words: conspiracy to commit illegal actions; complicity in a crime; measures of a criminal law nature; legal entity; Agent.

\section{JEL: K 14.}

DOI: https://doi.org/10.36477/2616-7611-2019-08-15

Постановка проблеми. Одним із основоположних принципів кримінального права України є принцип індивідуальної відповідальності особи, який передбачає, зокрема, можливість притягнення до кримінальної відповідальності лише фізичної особи, яка вчинила злочин. У Кримінальному кодексі України (КК України), не порушуючи вказаний принцип, у 2013 році, 3 метою виконання Плану дій щодо лібералізації Європейським Союзом візового режиму для України, було запроваджено норми, що входять в інститут застосування заходів кримінально-правового характеру щодо юридичних осіб [1]. Як вбачається з аналізу положень ст. 96-3 КК України, матеріальною підставою застосування таких заходів $є$ змова на вчинення 
Вісник Львівського торговельно-економічного університету. Юридичні науки. 2019. Вип. 8.

протиправних дій як самостійний склад злочину. Окрім того, ряд злочинів, що містяться у переліку вказаної статті полягають у створення та діяльності організованої групи або злочинної організації або їх кваліфікуючою ознакою названо вчинення злочину за попередньою змовою групою осіб або організованою групою. В обидвох випадках варто вести мову про змову на вчинення відповідних злочинів. Водночас, як вбачається, кримінальноправові норми у цій частині не охоплюють всіх випадків змови на вчинення протиправних дій, що вимагає коригування кримінального закону України та потребує додаткового наукового дослідження.

Постановка завдання. Основною метою цієї статті є встановлення доцільності застосування заходів кримінально-правового характеру щодо юридичних осіб за вчинення уповноваженою особою від імені та в інтересах юридичної особи змови на вчинення протиправних дій. Для досягнення поставленої мети вбачається за необхідне вирішення таких завдань: 1) виявити основні властивості змови на вчинення протиправних дій; 2) охарактеризувати матеріальну підставу застосування заходів кримінальноправового характеру щодо юридичних осіб у частині змови на вчинення протиправних діянь уповноважених осіб, які вчиняють злочини від імені та (або) в інтересах юридичної особи; 3) запропонувати шляхи вдосконалення кримінального законодавства України у цій частині.

Аналіз останніх досліджень та публікацій. Проблема застосування заходів кримінально-правового характеру щодо юридичних осіб ще не була предметом самостійного наукового вивчення. У наукових публікаціях пі торкалися такі дослідники, як 3.А. Загиней та О.З. Гладун. Водночас відповідна проблема перебуває на стику дослідження застосування заходів кримінально-правового характеру щодо юридичних осіб та співучасті у злочині, які розглядалися у наукових працях таких науковців, як П. П. Андрушко, О. А. Арутюнов, Ф. Г. Бурчак, В. К. Грищук, О. О. Дудоров, Г. П. Жаровська, К. П. Задоя, І. О. Зінченко, О. О. Кваша, М. І. Ковальов, С. Я. Лихова, В. О. Навроцький, Г. В. Новицький, М. І. Панов, О. Ф. Пасєка, А. А. Піонтковський, Ю. А. Пономаренко, О. В. Ус, С. О. Харитонов, С. Д. Шапченко, Г. З. Яремко, Н. М. Ярмиш, А. М. Ященко та інші. Таким чином, проблема застосування заходів кримінально-правового характеру щодо юридичних осіб за вчинення іï уповноваженою особою від імені та в інтересах юридичної особи змови на вчинення протиправних дій, $\epsilon$ актуальною та новою.

Виклад основного матеріалу. Сучасні науковці здебільшого визнають змову на вчинення злочину іманентною властивістю співучасті [2, с. 8; 3 , c. 117]. Наприклад, О.О. Кваша виходить 3 того, що згода (змова) на вчинення конкретного злочину характеризуе спільність умислу співучасників. Ця дослідниця наголошує «на важливості категорії змови для розуміння співучасті. У багатьох країнах цей термін (або ж «кримінальна змова») використовується законодавцем замість поняття «співучасть», наприклад, у США, Англії» [3, с. 117, 118]. I. А. Копйова вважає, що «змова є для співучасті відправною ознакою, тобто такою, за наявності якої злочин 
Вісник Львівського торговельно-економічного університету. Юридичні науки. 2019. Вип. 8.

набуває ознак співучасті, а отже, є їі обов’язковою ознакою. За відсутності змови на вчинення злочину у співучасті має місце лише односторонній суб'єктивний зв'язок, що виключає співучасть. За загальним правилом, наявність попередньої змови між співучасниками означає досягнення ними змови на вчинення злочину у співучасті до його початку, тобто до стадії замаху на його вчинення. Тому досягнення змови з особою, яка вже вчиняє злочин, тобто в перебігу його вчинення, означає, що змова між цими особами $\epsilon$ все-таки обов'язковою, хоча і не є попередньою» [4, с. 114]. 3 висловленою точкою зору варто погодитися. Змова, як зазначалося вище, є іманентною властивістю співучасті у злочині, яка дозволяє відмежувати змову від інших злочинних станів. Наприклад, від тих, що характеризуються одностороннім суб'єктивним зв'язком між особами, від закликів до вчинення протиправних дій, від так званого необережного співзаподіяння. Наприклад, змова відсутня у випадку вчинення особою публічних закликів до насильницької зміни чи повалення конституційного ладу або до захоплення державної влади, оскільки фактично одна особа проголошує, закликає іншу особу вчинити відповідні протиправні дії, вони наперед не домовляються про це. Змова на вчинення злочину, на нашу думку, свідчить про спрямованість дій співучасників, про умисний характер їх діяльності. Такий висновок випливає, зокрема, й зі значення слова «змова» в українській мові. Так, слово «зговір», яке зазвичай використовується як синонім до змови означає таємну угоду, змову з метою спільного здійснення певного наміру, а слово «змова» - таємну угоду для досягнення якої-небудь мети; взаємну домовленість кількох чи багатьох осіб про спільні дії [5, с. 449, 467]. Як вбачається 3 цих загальновживаних значень слів «зговір» та «змова», вони характеризують у кримінальному праві умисний характер діяльності кількох осіб (співучасників), оскільки зговір та змова спрямовані до досягнення відповідної мети, а предметом змови $є$ спільні дії співучасників, що притаманно умислу. Тому підтримуємо підхід у теорії кримінального права, відповідно до якого змова характерна будь-якій формі співучасті, іманентно притаманна для неї та включається у суб'єктивну ознаку співучасті у злочині.

Змова, на нашу думку, властива всім формам співучасті, що перераховані у ст. 28 КК України: групі осіб, групі осіб за попередньою змовою, організованій групі та злочинній організації. У кожній з цих форм змова відрізняється якісною ознакою, яка залежить від такої форми: чим більш небезпечною $є$ форма співучасті, тим більш диференційованою та детальною має бути сама змова. Так, поняття «зорганізованість» для організованих груп і злочинних організацій, що використовується у частинах 3 та 4 ст. 28 КК України фактично і є змовою співучасників, однак «вищого гатунку», ніж у випадку наявності неорганізованих форм співучасті у злочині. Так, на думку Н. Є. Попович, попередня зорганізованість є більш змістовною порівняно з попередньою змовою, відмінність між ними полягає у змісті попередньої змови [6, с. 230]. Зокрема, О. О. Кваша вважає, що планування, розподіл ролей, дисципліна, прикриття своєї діяльності всіма необхідними засобами виступають ознаками зорганізованості, які 
Вісник Львівського торговельно-економічного університету. Юридичні науки. 2019. Вип. 8.

формуються або з метою неодноразового вчинення злочинів, або в процесі такої діяльності та 3 метою іiі успішного продовження [7, с. 341-342]. Таким чином, змова притаманна будь-якій формі співучасті у злочині та залежить від цих форм: чим більш небезпечною є форма співучасті у злочині, тим більш складною має бути змова між співучасниками.

Також важливо звернути увагу на те, що змова притаманна як для співучасті «особливого» роду, так і співучасті з розподілом ролей, коли для кримінально-правової кваліфікації дій осіб потрібно визначати роль кожного співучасника у вчиненому діянні. Наприклад, якщо у випадку наявності групи осіб та групи осіб за попередньою змовою окрім співвиконавців, які $\epsilon$ безпосередніми учасниками відповідної групи, злочин вчиняють спільно 3 ними співучасники, які виконують інші функції (організатора, підбурювача або пособника), то наявність змови слід констатувати не лише для співвиконавців, учасників групи осіб або групи осіб за попередньою змовою, а й для інших співучасників.

В одній зі статей КК України передбачена така самостійна форма суспільно небезпечного діяння, як змова на вчинення протиправних дій. Йдеться про ст. 109 цього Кодексу, в якій передбачено таку альтернативну форму діяння, як змова про вчинення насильницької зміни чи повалення конституційного ладу або захоплення державної влади. Як випливає 3 переліку злочинів, що $\epsilon$ матеріальною підставою застосування заходів кримінально-правового характеру щодо юридичних осіб, вчинення уповноваженою особою злочину, передбаченого у ст. 109 КК України, від імені та в інтересах юридичної особи $є$ підставою застосування таких заходів (п. 4 ч. 1 ст. 96-3 КК України). Розмірковуючи далі про застосування заходів кримінально-правового характеру щодо юридичної особи за вчинення іiі уповноваженою особою від іменні та (або) в інтересах юридичної особи злочину у змові 3 іншими особами, варто звернути увагу на те, що застосування цих заходів можливе й у тому випадку, коли за злочини, що містяться у переліку (ст. 96-3 КК України), диференційована кримінальна відповідальність залежно від форми співучасті або встановлена відповідальність за створення та діяльність злочинних організацій або організованих груп.

Як вбачається з аналізу ст. 96-3 КК України, за змову до вчинення протиправних дій щодо юридичної особи можуть застосовуватися заходи кримінально-правового характеру у наступних випадках:

1) вчинення iї уповноваженою особою від імені та в інтересах юридичної особи таких злочинів: легалізація (відмивання) доходів, одержаних злочинним шляхом, вчинене за попередньою змовою групою осіб або організованою групою (частини 2, 3 ст. 209), використання коштів, здобутих від незаконного обігу наркотичних засобів, психотропних речовин, їх аналогів, прекурсорів, отруйних чи сильнодіючих речовин або отруйних чи сильнодіючих лікарських засобів, вчинене за попередньою змовою групою осію (ч. 2 ст. 306), активний підкуп службової особи юридичної особи приватного права незалежно від організаційно-правової форми, особи, 
Вісник Львівського торговельно-економічного університету. Юридичні науки. 2019. Вип. 8.

яка надає публічні послуги, службової особи публічного права, вчинений за попередньюю змовою групою осіб або організованою групою (ч. 2 ст. 368-3, ч. 2 ст. 368-4, частини 3, 4 ст. 369);

2) незабезпечення виконання покладених на іiі уповноважену особу законом або установчими документами юридичної особи обов'язків щодо вжиття заходів із запобігання корупції, що призвело до вчинення будь-якого iз злочинів, що наводилися вище;

3) вчинення iї уповноваженою особою від імені юридичної особи терористичного акту за попередньою змовою групою осіб (ч. 2 ст. 258), втягнення у вчинення терористичного акту, вчиненого за попередньою змовою групою осіб (ч. 2 ст. 258-1), створення терористичної групи чи терористичної організації (ст. 258-3), сприяння вчиненню терористичного акту, вчиненого за попередньою змовою групою осіб (ч. 2 ст. 258-4), фінансування тероризму, вчиненого за попередньою змовою групою осіб або організованою групою (частини 2, 3 ст. 258-5);

4) вчинення іiі уповноваженою особою від імені та в інтересах юридичної особи змови на вчинення насильницької зміни чи повалення конституційного ладу або захоплення державної влади, публічних закликів до насильницької зміни чи повалення конституційного ладу або до захоплення державної влади, а також розповсюдження матеріалів із закликами до вчинення таких дій, вчинені організованою групою (частини 1, 3 ст. 109), посягання на територіальну цілісність і недоторканність України, вчинене за попередньою змовою групою осіб (ч. 2 ст. 110), незаконне позбавлення волі або викрадення людини, вчинене за попередньою змовою групою осіб або організованою групою (частини 2, 3 ст. 146), захоплення заручників, вчинене організованою групою (ч. 2 ст. 147), порушення порядку фінансування політичної партії, передвиборної агітації, агітації 3 всеукраїнського або місцевого референдуму, вчинене за попередньою змовою групою осіб (ч. 4 ст. 159-1), підкуп виборця, учасника референдуму, вчинене за попередньою змовою групи осіб (ч. 4 ст. 160), створення не передбачених законом воєнізованих або збройних формувань (ст. 260), викрадення, привласнення, вимагання вогнепальної зброї, бойових припасів, вибухових речовин чи радіоактивних матеріалів або заволодіння ними шляхом шахрайства або зловживанням службовим становищем, вчинені за попередньою змовою групою осіб або організованою групою (частини 2, 3 ст. 262).

Вказаний вище перелік злочинів, які є підставою застосування заходів кримінально-правового характеру щодо юридичних осіб за вчинення іiі уповноваженою особою від імені та (або) в інтересах юридичної особи змови на вчинення протиправних діянь, можна вдосконалити. На нашу думку, у цьому переліку доцільно було $б$ вказати на злочини, які полягають у діяльності організованих груп та злочинних організацій, що передбачено як ознака основного складу злочину. Йдеться про створення злочинної організації (ст. 255), бандитизм (ст. 257), участь у транснаціональних організаціях, які здійснюють незаконну торгівлю анатомічними матеріалами 
Вісник Львівського торговельно-економічного університету. Юридичні науки. 2019. Вип. 8.

людини (ч. 5 ст. 143). Таке доповнення, на нашу думку, є важливим, оскільки діяльність вказаних видів злочинних спільнот характеризується підвищеним ступенем суспільної небезпеки, а в самому переліку злочинів у ст. 96-3 КК України містяться злочини, що передбачають відповідальність зі діяльність інших видів організованих груп та злочинних організацій.

Характеризуючи змову на вчинення протиправних дій як підставу застосування заходів кримінально-правового характеру щодо юридичних осіб звернемо увагу ще й на такому. На нашу думку, чинний КК України має прогалину у частині регулювання співучасті у злочині (а отже змови на вчинення протиправних дій) уповноважених осіб, які вчиняють злочини, що містяться у ст. 96-3 КК України. Так, в абз. 2 ч. 1 ст. 65 Закону України «Про запобігання корупції» передбачено наступне положення: «у разі вчинення від імені та в інтересах юридичної особи іiі уповноваженою особою злочину самостійно або у співучасті [виділено нами - Я. Р.] до юридичної особи у випадках, визначених КК України, застосовуються заходи кримінальноправового характеру» [8]. Відповідні положення містилися i в інших нормативно-правових актів, що й так не набули статусу закону. Так, у ст. 2 Закону України «Про відповідальність юридичних осіб за вчинення корупційних правопорушень» передбачалося наступне: юридична особа несе відповідальність, встановлену цим Законом, за вчинення від іiі імені та в іiі інтересах керівником такої юридичної особи, ㄲï засновником, учасником чи іншою уповноваженою особою самостійно або у співучасті будь-якого із злочинів, передбачених ст. 209, частиною 1 або 2 статей 235-4, 235-5, статтями 258-5, 364, 365, 368, 369 і 376 КК України [9]. Цей Закон набрав чинності, але не був уведений у дію [10].

В окремих міжнародних конвенціях містяться положення, які стосуються того, що у національному законодавстві доцільно передбачати відповідальність юридичних осіб у випадку, якщо уповноважена особа виступає не виконавцем, а іншим співучасником злочину. Наприклад, згідно 3 ч. 3 ст. 18 Кримінальної конвенції про боротьбу 3 корупцією відповідальність юридичної особи за пунктами 1 та 2 не виключатиме кримінального переслідування фізичних осіб, які вчиняють кримінальні злочини, згадані у п. 1, підбурюють до них або беруть у них участь [11]. На думку 3. А. Загиней, «... замовчування законодавцем важливої правової інформації (латентність тексту кримінального закону України) належать до недоліків нормотворчої техніки формулювання інституту застосування щодо юридичних осіб заходів кримінально-правового характеру, оскільки це може спричинити неоднакову інтерпретацію матеріальної підстави для їх застосування (ст. 96-3 КК України)» [12, с. 64]. Ця дослідниця пропонує такий шлях вирішення відповідної проблеми: вказати або у ч. 1 ст. 96-3 КК України, в якій у загальному вигляді формулюються підстави застосування заходів кримінально-правового характеру щодо юридичних осіб, або у примітці 1 цієї статті, в якій міститься дефініція поняття «уповноважена особа» на те, що уповноважена особа може вчинити злочин самостійно чи у співучасті [12, с. 64]. Погодимося з вказаним вище підходом 
Вісник Львівського торговельно-економічного університету. Юридичні науки. 2019. Вип. 8.

та пропонуємо обрати перший шлях: помістити відповідну вказівку у ч. 1 ст. 96-3 КК України, при формулюванні кожної підстави застосування заходів кримінально-правового характеру щодо юридичних осіб. Наприклад, початок п. 1 ч. 1 ст. 96-3 КК України пропонуємо сформулювати так: «1) вчинення їі уповноваженою особою від імені та в інтересах юридичної особи самостійно або у співучасті будь-якого із злочинів, передбачених у статтях...». Це, на нашу думку, усуне прогалини правового регулювання у сфері застосування заходів кримінально-правового характеру щодо юридичних осіб.

Висновки. 3 викладеного вище можна зробити наступні висновки:

1) змова $є$ іманентною властивістю співучасті у злочині, яка дозволяє відмежувати змову від інших злочинних станів. Змова притаманна всім формам співучасті, що перераховані у ст. 28 КК України: групі осіб, групі осіб за попередньою змовою, організованій групі та злочинній організації. У кожній 3 цих форм змова відрізняється якісною ознакою: чим більш небезпечною є форма співучасті у злочині, тим більш складною повинна бути змова між співучасниками;

2) змова притаманна як для співучасті «особливого» роду, так і для співучасті з розподілом ролей, коли для кримінально-правової кваліфікації дій осіб потрібно визначати роль кожного співучасника у вчиненому діянні;

3) за змову уповноважених осіб, які вчиняють злочини від імені та (або) в інтересах юридичної особи, щодо юридичних осіб застосовуються заходи кримінально-правового характеру, у випадку, якщо кваліфікуючою ознакою злочинів, названих у ст. 96-3 КК України, є вчинення їх за попередньою змовою групою осіб або організованою групою. Окрім того, застосування таких заходів можливе у випадку передбачення кримінальної відповідальності створення та діяльність організованих форм співучасті;

4) запропоновано розширити перелік злочинів у п. 4 ч. 1 ст. 96-3 КК України на вчинення шляхом вказівки на злочини, передбачені у ч. 5 ст. 143 (участь у транснаціональних організаціях, що здійснюють незаконну торгівлю анатомічними матеріалами людини), у статтях 255 (створення злочинної організації), 257 (бандитизм);

5) виявлено прогалину у правовому регулюванні у частині відсутності у нормах розділу XIV-1 Загальної частини КК України вказівки на те, що уповноважена особа може вчинити злочин від імені та в інтересах юридичної особи самостійно або у співучасті. Для іiі усунення запропоновано змінити формулювання початку речення кожного 3 пунктів частини 1 ст. 96-3 КК України. Наприклад, п. 1 ч. 1 цієї статті викласти у такій редакції: «вчинення піi уповноваженою особою від імені та в інтересах юридичної особи самостійно або у співучасті будь-якого із злочинів, передбачених статтями...».

\section{Література:}

1. Про внесення змін до деяких законодавчих актів України щодо виконання Плану дій щодо лібералізації Свропейським Союзом візового режиму для України стосовно відповідальності юридичних осіб: Закон України від 
Вісник Львівського торговельно-економічного університету. Юридичні науки. 2019. Вип. 8. 23 травня 2013 року № 314-VII. URL.: https://zakon.rada.gov.ua/laws/show/314-18\#n6 (дата звернення 16.04.2019).

2. Жаровська Г. П. Співучасть у злочині за кримінальним правом України: автореф. дис. канд. юрид. наук. Київ, 2004. 20 с.

3. Кваша О. О. Співучасть у злочині: структура та відповідальність: монографія. Луганськ: РВВ ЛДУВС ім. Е. О. Дідоренка, 2013. 560 с.

4. Копйова І.А. Змова на вчинення злочину як обов'язкова ознака співучасті. Проблеми законності. 2017. Вип. 137. С. 113-122.

5. Великий тлумачний словник сучасної української мови (з дод. і допов.) / Уклад. і голов, ред. В. Т. Бусел. Київ; Ірпінь: ВТФ «Перун», 2005. 1728 с.

6. Попович Н. С. Стійкість та попередня зорганізованість як ознаки організованої групи. Науковий вісник Львівського державного університету внутрішніх справ. 2006. № 3. С. 228-239.

7. Кваша О. О. Співучасть у злочині: сутність, структура та відповідальність: дис. доктора юрид. наук. Київ, 2013. 467 с.

8. Про запобігання корупції: Закон України від 14 жовтня 2014 року № 1700VII. URL.: https://zakon.rada.gov.ua/laws/show/1700-18 (дата звернення 16.04.2019).

9. Про відповідальність юридичних осіб за вчинення корупційних злочинів: Закон України від 11 червня 2009 року № 1507-VI. URL.: https://zakon.rada.gov.ua/laws/show/1507-17 (дата звернення 16.04.2019). (дата звернення 16.04.2019).

10. Про визнання такими, що втратили чинність, деяких законів України щодо запобігання та протидії корупції: Закон України від 21 грудня 2010 року № 2808-VI. URL.: https://zakon.rada.gov.ua/laws/show/2808-17 (дата звернення 16.04.2019).

11. Кримінальна конвенція про боротьбу з корупцією: міжнародний документ від 27 січня 1999 року. URL.: http://zakon2.rada.gov.ua/laws/ show/994_101 (дата звернення 16.04.2019).

12. Загиней 3. Основні недоліки нормотворчої техніки інституту застосування заходів кримінально-правового характеру щодо юридичних осіб. Науковий часопис Національної академії прокуратури Украӥни. 2017 № 4 (16). С. 58-78 URL.: http:/www.chasopysnapu.gp.gov.ua/chasopys/ua/pdf/4-2017/zaginej. pdf (дата звернення 16.04.2019).

\section{References:}

1. Pro vnesennia zmin do deiakykh zakonodavchykh aktiv Ukrainy schodo vykonannia Planu dij schodo liberalizatsii Yevropejs'kym Soiuzom vizovoho rezhymu dlia Ukrainy stosovno vidpovidal'nosti iurydychnykh osib: Zakon Ukrainy vid 23 travnia 2013 roku № 314-VII. URL.: https://zakon.rada.gov.ua/laws/show/314-18\#n6 (data zvernennia 16.04.2019).

2. Zharovs'ka H. P. Spivuchast' u zlochyni za kryminal'nym pravom Ukrainy: avtoref. dys. kand. iuryd. nauk. Kyiv, 2004. 20 s.

3. Kvasha O. O. Spivuchast' u zlochyni: struktura ta vidpovidal'nist': monohrafiia. Luhans'k: RVV LDUVS im. E. O. Didorenka, 2013. 560 s. 
Вісник Львівського торговельно-економічного університету. Юридичні науки. 2019. Вип. 8.

4. Kopjova I.A. Zmova na vchynennia zlochynu iak obov'iazkova oznaka spivuchasti. Problemy zakonnosti. 2017. Vyp. 137. S. 113-122.

5. Velykyj tlumachnyj slovnyk suchasnoi ukrains'koi movy (z dod. i dopov.) / Uklad. i holov, red. V. T. Busel. Kyiv; Irpin': VTF «Perun», 2005. 1728 s.

6. Popovych N. Ye. Stijkist' ta poperednia zorhanizovanist' iak oznaky orhanizovanoi hrupy. Naukovyj visnyk L'vivs'koho derzhavnoho universytetu vnutrishnikh sprav. 2006. № 3. S. 228-239.

7. Kvasha O. O. Spivuchast' u zlochyni: sutnist', struktura ta vidpovidal'nist': dys. doktora iuryd. nauk. Kyiv, 2013. $467 \mathrm{~s}$.

8. Pro zapobihannia koruptsii: Zakon Ukrainy vid 14 zhovtnia 2014 roku № 1700 VII. URL.: https://zakon.rada.gov.ua/laws/show/1700-18 (data zvernennia 16.04.2019).

9. Pro vidpovidal'nist' iurydychnykh osib za vchynennia koruptsijnykh zlochyniv: Zakon Ukrainy vid 11 chervnia 2009 roku № 1507-VI. URL.: https://zakon.rada.gov.ua/laws/show/1507-17 (data zvernennia 16.04.2019). (data zvernennia 16.04.2019).

10. Pro vyznannia takymy, scho vtratyly chynnist', deiakykh zakoniv Ukrainy schodo zapobihannia ta protydii koruptsii: Zakon Ukrainy vid 21 hrudnia 2010 roku № 2808-VI. URL.: https://zakon.rada.gov.ua/laws/show/2808-17 (data zvernennia 16.04.2019).

11. Kryminal'na konventsiia pro borot'bu z koruptsiieiu: mizhnarodnyj dokument vid 27 sichnia 1999 roku. URL.: http://zakon2.rada.gov.ua/laws/ show/994 101 (data zvernennia 16.04.2019).

12. Zahynej Z. Osnovni nedoliky normotvorchoi tekhniky instytutu zastosuvannia zakhodiv kryminal'no-pravovoho kharakteru schodo iurydychnykh osib. Naukovyj chasopys Natsional'noi akademii prokuratury Ukrainy. 2017. № 4 (16). S. 58-78 URL.: http://www.chasopysnapu.gp.gov.ua/chasopys/ua/pdf/42017/zaginej. pdf (data zvernennia 16.04.2019). 